\title{
One Metropolis, two scenarios. Sustainable Urban Development Contradictions in the Metropolitan Area of Lima.
}

\author{
Sally, TORRES, Universidad Ricardo Palma, Peru
}

\begin{abstract}
Despite the new urban planning thinking and legislation evolution since 2016 towards sustainable development, in practice, there is a limited legal framework for planning which makes it more challenging for local governments. As a result, two main scenarios have taken place in the Metropolitan Area of Lima: the unsustainable urban growth at the metropolitan level, and sustainable urban development building at the local level. In an attempt to contextualize the current state of Lima's territorial planning, the research captures the nature and trajectory of this contradiction to conduct the various trade-offs inherent in sustainable urban development. The results show that urban planning unawareness, and fragmented governance without continuity across government periods, have led to distrust at the metropolitan level diminishing its urban development towards social and environmentally sustainable development. However, integrated planning and collaborative governance with stakeholders enabled the strengthening of resilience with risk mitigation in informal urban settlements at the local level. The research concludes that new transformations call for new behaviors. Consequently, appropriate collaborative governance becomes a collective power for sustainable urban development growth.
\end{abstract}

\section{Keywords}

Lima Metropolitan Area, Sustainable Urban Development, Urban Governance, Urban Planning, Informal Urban Settlements.

\section{Introduction}

Today, we are witnessing an unprecedented growth in urbanization and population in cities, along with the rise of the effects of natural disasters due to climate change. The adoption of the Sustainable Development Goals (SDGs) and the 2030 Agenda for Sustainable Development in 2015 are proof of the global, urgent, and inclusive action in this matter. This because sustainable development can prevent environmental and social disasters (Independent Group of Scientists, 2019).

Sustainable Development is the development pattern that responds to the present generation's needs without compromising resources for future generation's needs (Kanuri et al., 2016). The crucial step takes place when we understand that cities are also a source of solutions and not only its problem's cause. If the city is well planned and managed, urbanization can be a vital instrument for achieving sustainable development (United Nations (Habitat III), 2017). Therefore, making urban areas into sustainable cities will take place through various processes of sustainable urban development (Williams, 2010). This with a multidimensional and integrated planning approach in which social inclusion, environmental sustainability, 
and economic dynamism complement each other (Jordán, Riffo and Prado, 2017). However, the aim of making sustainable cities is very contradictory in the global picture because urban problems affect more critically developing countries where the population rapidly rises while resources decrease (Williams, 2010).

In the Latin-America and the Caribbean, a region mostly conformed by developing cities is still facing bigger challenges for urban-territorial policies across levels of governance to implement sustainable development (Winchester, 2006). This situation relies mainly on social inequalities and the weak urban policy elaboration that takes place unrelated to the trajectory of growth and urban development of cities (Jordán, Riffo and Prado, 2017). Furthermore, climate change and natural disasters exacerbate existing inequality. The poorest populations are the most vulnerable as they have fewer resources to recover from the shocks of climate change (Inter American Development Bank, 2020). Therefore, each country faces challenges for building sustainable development highlighting the middle-income countries (United Nations, 2015).

Since the adoption of the SDGs, 35 of 110 countries have informed the incorporation of the Goals into national budgets or were considering such action (Independent Group of Scientists, 2019). Yet Peru is one of the five countries that report less than $20 \%$ of the official Sustainable Development Goal indicators in 2019 (Castro and Valbuena, 2020). This because significant challenges remain in Peru to achieve SDG 11 of sustainable cities (Sachs et al., 2020). Its 11 metropolises and particularly the Lima Metropolitan Area with more than 10 million inhabitants (UN-Habitat, 2020), are still characterized by common Latin-American barriers on governance and financing structures, political will, and the lack of information (Jordán, Riffo and Prado, 2017). Consequently, accelerated urbanization has been taking place through the informal and illegal occupation of the territory generating poverty belts in urban peripheries equivalent to $36.1 \%$ of the urban population (World Bank, 2015).

In an attempt to contextualize the current state of Lima's territorial planning, the research aims to capture the nature and trajectory of sustainable development contradictions. For this, the research is organized into five sections. The next section explains the need for building sustainable urban development. The following two sections focus on the study area and the results from the two scenarios. Finally, the discussions and conclusions. Hence, the research will contribute to the scientific assessments that will help Lima Metropolitan Area to conduct the various trade-offs inherent in sustainable urban development, and thus, constitute one of the first approaches due to limited existing research in urban planning in Lima city.

\section{The need for building sustainable urban development}

\subsection{Role of governments}

Given the immense challenges for sustainable urban development, the 2030 Agenda for Sustainable Development took place in 2015 as a new global project to shape our common future by leaving no one behind through seventeen sustainable development goals (SDGs) (United Nations, 2015). The goal SDG 11 focused on cities and human settlements, represent the key to empowering cities. It puts urbanization at the heart of sustainable development (Kanuri et al., 2016) because governments can affect the well-being of the entire planet and people in collaborative partnerships (Independent Group of Scientists, 2019). In this sense, government achievements should complement the entire SDG framework through interactions between goals and targets, and partnerships across levels of governance, sectors, and all stakeholders.

Then, a New Urban Agenda (NUA) has established in 2016 at the United Nations Conference on Housing and Sustainable Urban Development (Habitat III). A shared vision to strengthens the role of national and local governments in the achievement of sustainable urban development. This by setting standards and principles of urban areas as an engine for development. Sustainable Urban Development would improve the quality of life in urban environments through a more balanced and equitable urban development, 
promoting social inclusion, and enhancing resilience and environmental sustainability (Kanuri et al., 2016). The NUA will seek to create a mutually reinforcing relationship between urbanization and development to become parallel vehicles for sustainable development since it implicitly believes that by addressing SDG 11, we will be acting on all the other SDGs (United Nations (Habitat III), 2017). However, an unbalanced situation towards sustainability remains with a wide disparity in the integration's level of the SDGs into the nation's agendas (Independent Group of Scientists, 2019).

The crucial leadership of governments to put in practice sustainable urban development (Espey and Revi, 2018), (Global Taskforce; UN-Habitat; UNDP, 2016) faces main challenges such as weak institutions and low power of implementation. Therefore, the transformative power of socioenvironmental-economic systems should take place globally (Independent Group of Scientists, 2019). States must fully understand the interlinkages across them and prioritize in the short-term. However, the heavy load of implementation lies in local governments that will need help to achieve their goals. Hence, guidelines and frameworks were developed by international agencies to guide cities and human settlements to become inclusive, safe, resilient, and sustainable. From this sort of tools, the Getting Started with the SDGs in the Cities, and the Urban and Territorial Planning International Guidelines which focuses on urban governance and urban planning respectively has been considered to strengthen the role of local governments in building sustainable urban development.

According to the Getting Started with the Cities is required five conditions to improve the quality of life in urban environments (Kanuri et al., 2016). First, decentralized governance through an appropriate division of powers between different levels of government. This with the growing responsibilities of local governments to ensure inclusive decision-making (Kanuri et al., 2016). The improvement of its quality depends on the political will. Second, integrated local governance which is based on vertical and horizontal coordination mechanisms, as well as territorial coordination between local governments (Espey and Revi, 2018), (Kanuri et al., 2016). Third, municipal finance through financing mechanisms to ensure the spent of public funds on projects and initiatives directly responding to sustainable development (Kanuri et al., 2016), (United Nations, 2015). Fourth, government capacity development through initiatives that can focus on enhancing skills and abilities among local governments in short- medium- and long-term processes. Finally, the policy frameworks. It consists of a set of principles and long-term goals that form the basis of legislation and regulations to lead the planning and development of cities (Kanuri et al., 2016). Thus, national urban policies should enable policy frameworks for sustainable urban and local development (Espey and Revi, 2018), (Kanuri et al., 2016).

Regarding the International Guidelines on Urban and Territorial Planning, twelve principles have been established to support the implementation of the NUA, and the 2030 Sustainable Development Agenda (UN-Habitat, 2015b). These principles are organized into four main components. First, urban policy and governance to highlight the role of urban planning as an integrative and participatory decision-making process. It requires participation, inclusion, transparency, and accountability (UN-Habitat, 2015b). Second, urban and territorial planning for sustainable development. For this, the integration of the three dimensions: social development, economic growth, and environmental protection, is key and requires political commitment and involvement of all stakeholders (UN-Habitat, 2015b). Third, urban and territorial planning components such as spatial, institutional, and financial dimensions to promote compact cities and synergies between territories and to translate political decisions into actions (UN-Habitat, 2015b). Finally, implementation and monitoring (UN-Habitat, 2015b).

Furthermore, three reports are considered to complement the general overview. The Global Sustainable Development Report 2019 that aims to accelerate the transformation focused on the needs of those living in informal settlements (Independent Group of Scientists, 2019). Then, the National Report Peru Habitat III as a diagnosis of housing, urban development, and urban planning (Ministerio de Vivienda, 2016b). And, 
the Lima Prosperity Index Measurements 2015 that highlights the main challenges and recommendations to achieve Sustainable Urban Development (UN-Habitat, 2015a). Finally, the document Steering the Metropolis, Metropolitan Governance for Sustainable Urban Development (Gómez-Álvarez et al., 2017) is also considered for the assessments. A comparative analysis of metropolitan governance worldwide that addresses challenges and constitutes a tool for achieving sustainable urban development.

\subsection{Challenges of the Metropolitan Area of Lima}

Today the Metropolitan Area of Lima is an unplanned, unsafe, and inequitable city (García Q. et al., 2015). The absence of policies and legal framework for development and planning at the national level is one of the main problems that has led to managing its territory with outdated metropolitan urban planning instruments for the last twenty years. Consequently, there is $70 \%$ of informal housing construction in Peru (Ministerio de Vivienda, 2016b), leading Lima to face three main challenges: territorial fragmentation, institutional vulnerability, and multiple hazard exposition. The Territorial Fragmentation challenge is along with the three levels of government: municipal, metropolitan and regional without appropriate coordination mechanisms that are more challenging with the presence of forty-three district municipalities (Metzger et al., 2015). The next challenge is Institutional Vulnerability such as unequal action capacities between municipalities, overlapping of functions, and weaknesses in territory control (Metzger et al., 2015). Finally, the Multiple Hazard Exposition due to its geographical location. Lima is exposed to earthquakes and tsunamis while the ravines and valleys area, where the informal urban settlements have established, suffers frequent alluviums and devastating floods.

Therefore, the research takes place as descriptive and critical research based on the international literature review, analysis of political and scientific publications, and review of media articles from 2010 onwards. Likewise, the assistance of several forums with the participation of the representatives from the public and private sector, NGOs, and academia, constituted one of the high-level sources of information. The methodology consists of developing an urban planning approach since it is the core component of urban governance (UN-Habitat, 2015b) towards sustainable urban development. This by considering guidelines and reports focused on urban governance and urban planning. Furthermore, the Independence District case study has been analyzed to contrast the unsustainable urban development in the Metropolitan Area of Lima. This with particular attention to the empowerment of vulnerable and disadvantaged groups for building and advocating for evidence-based in sustainable urban development.

\section{Study Area}

The location of the Metropolitan Area of Lima on the shores of the Pacific Ocean and at the foot of the Andes in a coastal desert provides a variety of urban landscapes composed of coast, rivers, valleys, and mountains. It is also characterized by historic heritage with a wide cultural wealth. However, its historic urban landscape is not articulated to the modern urbanization, nor accounted for the relationship between natural and built environments. This because it has taken place unrelated to social and environmentally sustainable development.

Due to rapid and uncontrolled urbanization, it has a continuous growth of the population with more than 10 million inhabitants that is equivalent to the third part of the country's population. It is a national metropolis holding $50 \%$ of the urban population of the country (World Bank, 2015). Consequently, it has developed a territorial organization of four sectors: North Lima, South Lima, East Lima, and Lima Centre. The concentration of political-administrative, infrastructure, technology, commercial, and services functions resides in the Lima Centre sector considered as the urban core (UN-Habitat, 2015c). In contrast, the other sectors are characterized by informal urban settlements due to the migrations to the capital city situated in places more vulnerable such as steep slopes and river edges. Consequently, there is a lack of 
social infrastructures such as decent housing, access to quality basic services, as well as public spaces and green areas (UN-Habitat, 2015a). Although El Callao seems to be part of the Metropolitan Area of Lima (Figure 1), it is a Constitutional Province that is autonomous in its technical-administrative processes. Therefore, the political-administrative structure of the Metropolitan Area of Lima is divided into forty-three districts which are governed by its respective municipality, and by the Metropolitan Municipality of Lima.

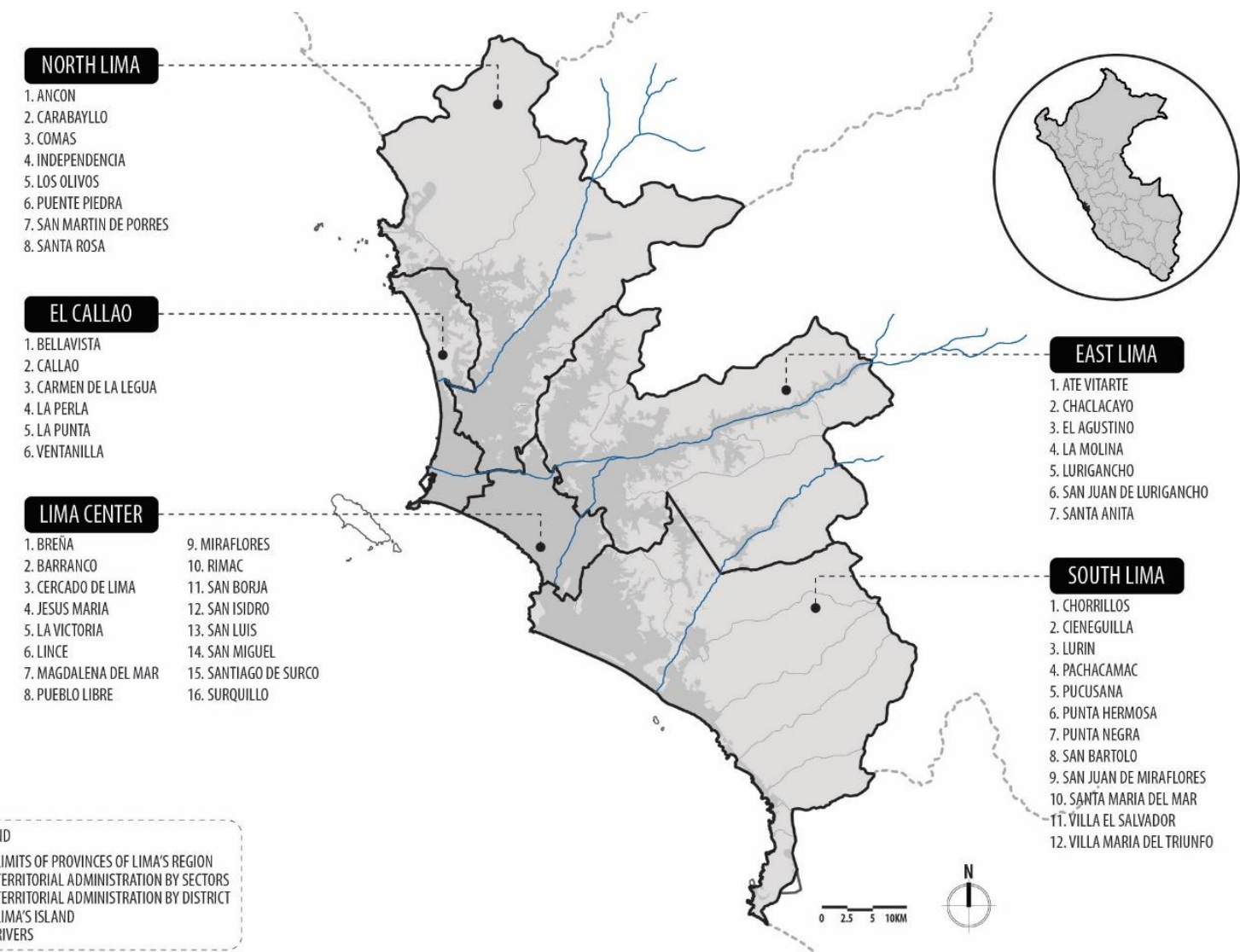

Figure 1. Metropolitan Area of Lima's Location, and Territorial Administration. Source: Author archive.

The absence of a well-established urban growth policy at the metropolitan level allowed that national housing policies had greatly influenced on Lima's urban transformation. This through a sharp intensification of urbanization in two prevalent ways formal and informal, both without coordination and connection with local urban development (Ferdandez-Maldonado, 2016). Formal urbanization by the intensification of land use was promoted by real estate developers, state, or private to offer it to the population of middle- and upper-income classes in the downtown areas. In contrast, informal urbanization by promoting peripheral informal expansion due to migrations to the capital city in steep slopes and river edges. This by taking first the land informally and illegally by poor-income classes who create a community that aims the management of regularization of their situation after the occupation of land.

Besides, vertical densification took place disproportionately to the provision of public facilities and spaces. It suffers from severe deficiencies in its basic infrastructure such as high infrastructure, quality housing, appropriate transportation, as well as protection of green areas, and ecologically agricultural areas (Ministerio de Vivienda, 2016b). As a result, strong socio-spatial inequalities, fragmentation of urban space, and vulnerability to risk disasters and social security are created and deepened between the city center and the peripheries (Marcés, Miyashiro and Wiese, 2016). Although the relation between environment and urbanization has been strengthened through a national commitment to adapt to climate change (Ministerio de Vivienda, 2016b), it must be translated into improvements in urban development and implementation processes. 
The Ministry of Housing (MVCS) has recognized this challenging situation through the World Bank's statement in the RAS Program-Planning, Urban Land and Housing Offer in 2015 (Ministerio de Vivienda, 2016b). Likewise, the national government through the National Report Peru for Habitat III has also recognized it to achieve sustainable urban development and the urban legislation reform. Therefore, to enhance the urban legislation, the MVCS has proposed the Draft Law for the Creation of the National System for Sustainable Urban Development (SINADUS) in 2015 to allow adequate interaction between different actors, sectors, and levels of government (Ministerio de Vivienda, 2016a). Likewise, the Sustainable Urban Development Policy proposal in 2018 to regulate and guide the economic, social, and environmental processes for sustainable urban development through six principles (Ministerio de Vivienda, 2018). Furthermore, the Territorial Conditioning and Sustainable Urban Development Regulations (RATDU) in 2016 that becomes the only normative in this matter.

In short, although Peru has stated its new vision towards sustainable urban development by presenting several initiatives in the National Report of Peru for Habitat III in 2016, these regulations that seek to regulate and guide urban development, have been drafted without a framework law covering them. Consequently, there is a great absence of urban planning tools in local governments that leads to relying on zoning maps and that sometimes are changed due to incoming private projects. Additionally, those who achieve planning tools lose continuity across government periods. Furthermore, even if technical and financial support for local governments were provided by the MVCS, they have no significance. This because there is not a national urban development policy and an official term for planning in the Peruvian legislation (Fernández-Maldonado, 2019). However, under the same national context of a limited legal framework for planning, two different scenarios have taken place between the metropolitan and local governments.

\section{Results from the two scenarios}

\subsection{Metropolitan Level}

The existence of studies such as the 'State of the City in Lima' in 2015, to reflect on the model of the city that it builds to improve the quality of life of its citizens, and with urban governance and planning recommendations oriented to sustainable urban development, in practice, have not been implemented. Today, Lima has an important population in a situation of poverty that continues to grow in a disorderly way due to the private and public investments unrelated to urban and rural development but is related to private self-interests.

The strengthening of urban governance and legislation recommendation through the enhancement of institutional capabilities has not taken place at all. The metropolitan governance key role in achieving territorial development by bringing together the forty-three local governments and encouraging their development lacks for drivers and an articulated urban policy for more integrated governance. Drivers such as leadership, collaboration, and coordination between local and regional governments, as well as horizontal coordination across sectors, are crucial for an integrative and participatory decision-making process. However, there is an overlapping of powers and functions due to uncleared roles because when the MML is about to implement a project, it requires the municipality's permission (Integracion, 2020). Likewise, even if authority was created to supervise the coastal area, in practice, eleven institutions have powers over it, including six local governments. Legal and normative frameworks should be established coherently to clarify and simplify the existing laws and metropolitan ordinances, and therefore managing urban development under the same goal.

Likewise, the stagnation of institutional capabilities regarding urban development relies on two main reasons: unawareness of urban planning, and the absence of suitable and specialized professionals on the 
subject. The composition of local governments is not appropriately qualified because lacks real comprehension and interested in urban governance and urban planning. Besides, there are bureaucratic barriers and self-interests for excluding interdisciplinary professionals focused on sustainable development, diminishing the opportunity to generate richness knowledge.

The next recommendation on urban planning through the elaboration of the Lima and Callao Metropolitan Plan for the next 20 years is the greatest omission. The MML currently remains without any valid Metropolitan Development Plan after the previous one expired because the authorities made no effort (Ferdandez-Maldonado, 2016). The latest attempt to have a metropolitan planning tool called PLAM 2035 in 2014 for the Lima Metropolitan Area and El Callao, has been disapproved and paralyzed. This incident showed two additional weaknesses: distrust of political processes, and vulnerability on political periods. The unclear explanation to paralyze this process to focus on other projects (Integracion, 2020) diminishes the transparency and accountability of metropolitan governance, leading to distrust among citizens. Additionally, this distrust increases since political decision continuity depends on the following elected official's will. There are two relevant examples. One is the PLAM 2035 that was proposed by the previous metropolitan government but was rejected by the following government. In contrast, even with studies and approved projects, there is no continuity, e.g. the electric train project that took decades for its implementation.

Nevertheless, since late 2019, the MML has started to elaborate on the Metropolitan Urban Development Plan 2021-2040 (PLANMET 2040). A plan focused on land regulation and management that aims to consider the social, economic, and environmental dimensions through five strategic guidelines (Instituto Metropolitano de Planificacion (IMP) and Municipalidad Metropolitana de Lima (MML), 2020). However, there are some contradictions to achieve sustainable development.

One main contradiction is that although it will allow the territorial ordering with a new division based on Lima sectors, which means better territorial management, it does not consider the inclusion of El Callao Constitutional Province. This means that the inter-institutional cooperation framework agreement signed with both Municipalities and the housing sector this year to achieve sustainable development has been ignored. Consequently, it continues to manage its territory without coordination with El Callao Province, knowing that the functioning of both provinces depends on each other (Metzger et al., 2015). The next contradiction is that although it has been taken place as a participatory process, it only focuses on public consultation. The participation and collaboration of other stakeholders such as more academia, interdisciplinary professionals, and other NGOs that have performed relevant planning tasks in some peripheral districts in Lima, are not yet included. Furthermore, according to the First Urban Dialogue in this present year, a space to know the PLANMET 2040's integration with the sustainable development goals and the climate change approach, uncertainties are perceived. There is not a clear approach to how to articulate PLANMET 2040 with international guidelines. Consequently, the discussions have been usually focused on legal and normative topics.

\subsection{Local Level}

Independence District, located on the periphery of Lima at the North Lima sector, is strongly characterized by informal urban settlements due to rapid and uncontrolled urbanization. Its location on steep slopes even with more than 20 degrees, did not impede to continue living with an absence of social infrastructure (Figure 2). Therefore, vulnerability and risk to natural (earthquakes and heavy rains associated with the El Niño phenomenon) and man-made hazards have critical conditions (Centro de Estudios y Prevencion de Desastres - PREDES, 2018). The risk areas represent 34\% of the occupied area of the district and compromise $44 \%$ of the total population with a High-risk level (Municipalidad de Independencia; Centro de Estudios y Prevencion de Desastres - PREDES, 2018a). Nevertheless, with a real awareness of this 
situation, Independence Municipality has focused on the resilience strengthening of the most vulnerable population. This due to the 'Disaster Risk Reduction Program on Vulnerable Areas' funded by USAID/OFDA from 2014-2018 and the technical support of the Center for Studies and Disaster Prevention (PREDES). As a result, the elaboration of the Urban Development Plan (PDU) 2014-2024 and implementation of the Disaster Risk Prevention and Reduction Plan (PPRRD) 2018-2021 took place as participatory planning.

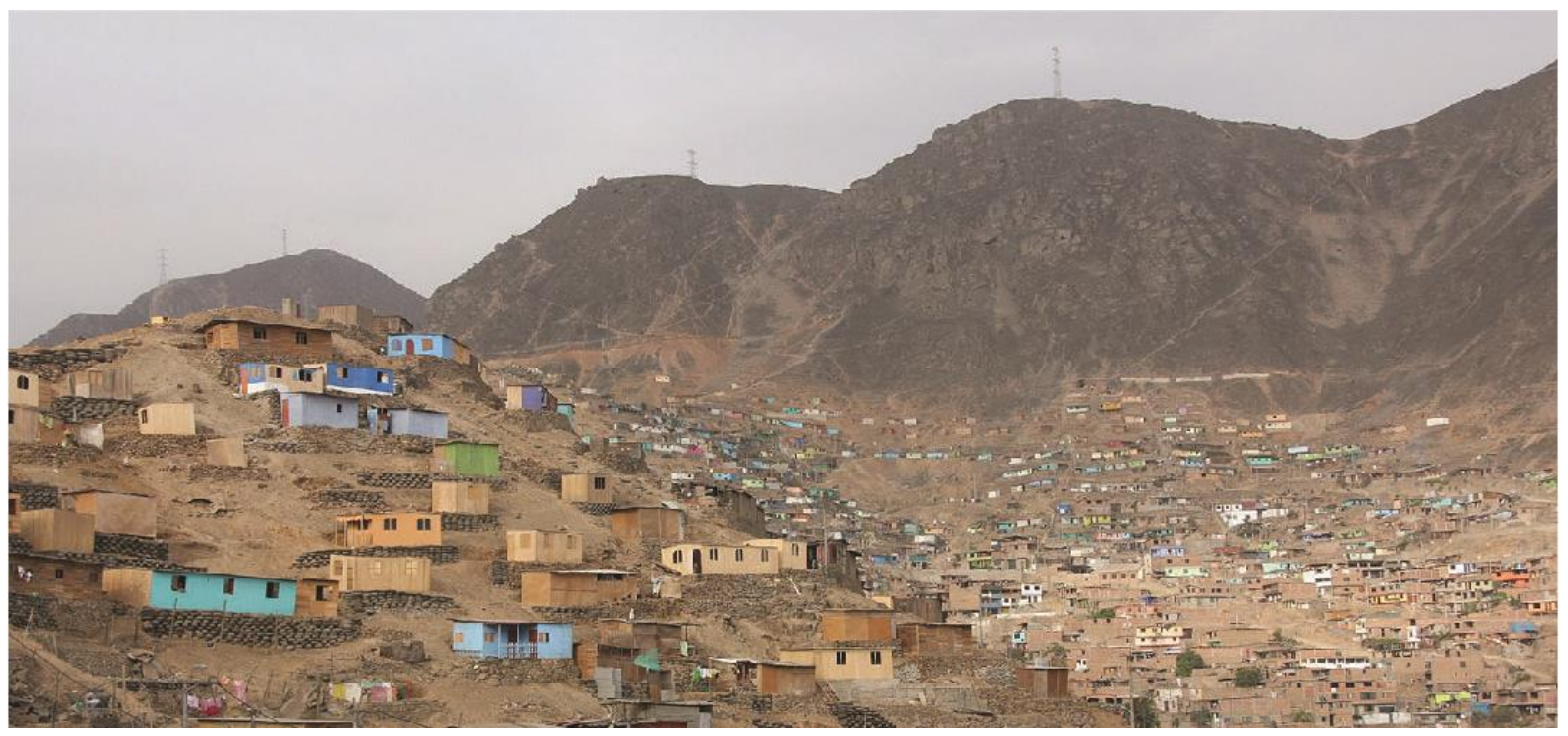

Figure 2. Independence Context. (Source: Centro de Estudios y Prevencion de Desastres - PREDES, 2014)

The PDU 2014-2024 promotes the three components for sustainable development. Social inclusion by recognizing the distinct needs of various groups focusing on the most vulnerable. Economic growth by enabling a framework for new economic opportunities especially for micro-enterprises. Environmental protection by generating a spatial framework to protect and manage the natural and built environments. Furthermore, it has developed a Land-Use Planning proposal, based on vulnerability and risk studies, to stand for a new special regulation to avoid occupation in areas of steep slopes (Municipalidad de Independencia; Centro de Estudios y Prevencion de Desastres - PREDES, 2018b). However, the PDU has not been approved, and even if the specific observations have been attended, and resubmitting it in 2018 with the assistance of PREDES, to date it is still under evaluation.

The methodology of participative sustainable planning has allowed developing an integrative and participatory decision-making process because public participation workshops were considered as a mechanism for the validation of the results on the diagnosis and the proposals. Hence, local democracy, transparency, and accountability highly strengthen urban governance. Consequently, this experience has led to the implementation and monitoring of each component of the Disaster Risk Reduction strategy by considering the community as active actors. The main results are related to the capacitation on natural hazards for both community and authorities, the reinforcement of housing in informal urban settlements, and the afforestation on the slopes including stakeholders' participation (Centro de Estudios y Prevencion de Desastres - PREDES, 2018). The Urban Afforestation on the steep slopes was the most pioneering as improvement of urban expansion control, environmental management, and disaster risks, not only as a pilot project but as a process that converged political wills (Leon, 2018).

The case study of the Independence district achieved four main aspects of urban governance whose implementation through disaster risk measures was recognized at the national (Lozano, 2018), and international level. First, the capacity building under the approach of empowering citizens through horizontal relationships for the knowledge interchange. Second, improved coordination between local government and community on the elaboration, implementation, and management of the urban plan to 
generate empathy and trust. Third, the existence of alliances with diverse stakeholders such as academia and NGOs. Fourth, the efficient management by creating a technical commission for Urban Control, Forestation, and Monitoring of High-Risk Disaster Areas. This also thanks to the International Forum 'Reducing the Risk of Disasters in Vulnerable Cities' in Lima 2017. A space that accounted for the participation of international specialists, representatives of the national and local government, research institutions, and civil society, where shared lessons and challenges for better implementation.

\section{Discussions and Conclusions}

Although every Government and every citizen has a responsibility to ensure the Sustainable Development (Independent Group of Scientists, 2019), the Metropolitan Area of Lima has grown unsustainable because urbanization and development took place without any urban planning criteria. As a result, it relies on zoning regulations that are not always respected due to the convenience of the local authorities. The incapacity of the national government to translate political decisions into actions to support the integration of cities and territories is one main challenge. Therefore, the main structural problem of Peru is the insufficient level of urban and territorial planning because it does not have a Territorial Ordering Law, and no regulation governs properly. Consequently, the absence of legal and institutional policy frameworks for sustainable development defeat great changes in the way people, organizations, and governments could function for the planning and development of cities.

The presence of peripheral informal urban settlements in the Metropolitan Area of Lima represents another main challenge. There is not enough space to relocate this population, nor financial resources to provide social infrastructure. As a result, informality and illegality are trends that will continue to attempt to occupy not only high-risk levels territories but also protected green areas, and ecologically agricultural areas. This because of the splitting of families and migration continuity. In this sense, sustainable urban development needs to be on the government's agenda by really understanding its approach and by truly sharing this motivation. As the urban expansion will continue to put enormous pressure on local governments, it means opportunities for social and political transformation will come.

The fact of the Metropolitan Area of Lima without updated planning tools for twenty years has diminished its efficiency and its opportunity to be the engine for growth leading to uncontrolled urban planning and governance. However, the case study of Independence Municipality shows that the inclusion of diverse stakeholders at varying levels of responsibility were crucial for strengthening resilience through risk mitigation. Besides, leadership, political will, and shared motivation were the drivers for collaborative governance that became the collective power for building sustainable urban development. Therefore, the nature of this contradiction is related to urban planning unawareness and fragmented governance without continuity that leads to an uncertain trajectory.

The urban planning unawareness is reflected in the current elaboration of the metropolitan planning tool. To start, these processes should be taken under an interdisciplinary approach. This by considering suitable professionals focused on sustainable development. Likewise, the Metropolitan Area of Lima needs to be developed under the approach of a structural plan by applying the planning tools and management mechanisms for increasing efficiency and equity through main projects (Gómez-Álvarez et al., 2017). For instance, a structural plan for the Metropolitan Area of Lima and El Callao because both functions are mutually dependent, with continuity in its implementation by local governments. Thus, the Peruvian planning approach will not be usually oriented on land-use planning, and urban projects as a basis of intervention on urban development (Fernández-Maldonado, 2019). For this, the generation of knowledge to understand the city structure by considering also the heritage, rural, and natural areas and its development with qualitative and quantitative analyses (lovene et al., 2018) is key. 
The fragmented governance without continuity along government periods remains even with new urban planning thinking and legislation evolutions since 2016. Although coordination with sectors, agencies, stakeholders, and its own institutions' affiliations is much more complex, coordination with additional forty-three municipalities makes it more difficult to establish a dialogue to know the different realities especially of sectors that are usually excluded. Then, the PLAM 2035 disapproval in 2015, and the twoyear-long process for the Independence PDU 2014-2024 approval have also shown individualism that limits the development plans' continuity. As a result, distrust has increased on citizens and local governments. Therefore, the clear need to provide basic services (water, sewerage, electrical energy, and transportation) and equipment in informal urban settlements is also uncertain. This situation becomes even more contradictory since for these processes it is necessary to have property titles to apply to financial resources.

Within this scenario, key stakeholders with different criteria should be included to plan and manage together the use of resources leading to collaborative governance without vertical and horizontal boundaries. Although this new model may seem not easy for the MML, since agreements and consensus may take more time, is the most appropriate form to evolve towards sustainable urban development. Likewise, public participation should be strongly based on direct dialogue with authorities to generate the trust of citizens in their local governments. Hence, more governance instruments are required to enhance legal and institutional frameworks, efficient urban management, improved coordination, and consensusbuilding approaches. This for the continuity of the implementation of planning tools across levels of government and along government periods.

Sustainable urban development needs planning, developing, and managing metropolitan regions through significant changes. The MML will only get closer to this goal if all stakeholders leave aside individualism to achieve collaborative governance. Thus, it will be able to achieve not only the elaboration of planning tools, but above that, its implementation, and monitoring. Urban planning value for cities especially in developing countries should be known and understood. We are all builders for sustainable development, and for this reason, only a collective approach could become a collective power for sustainable urban development growth because new transformations call for new behaviors.

\section{References}

Castro, F. and Valbuena, N. (2020) 'Cods, 2020. Indice ODS 2019 para América Latina', Bogota: Centro de los Objetivos de Desarrollo Sostenible para América Latina y el Caribe, p. 9. Available at: https://cods.uniandes.edu.co/wp-content/uploads/2020/06/Índice-ODS-2019-para-AméricaLatina-y-el-Caribe-2.pdf. (Accessed: 16 August 2020)

Centro de Estudios y Prevencion de Desastres - PREDES (2018) 'Sistematizacion del Programa: Reduccion del riesgo en areas vulnerables del distrito de Independencia', Lima: Centro de Estudios y Prevencion de Desastres (PREDES), pp. 23-54. Available at: https://www.muniindependencia.gob.pe/desastres/tab/pdf/A.-Sistematiz-Prog-USAIDIndependencia.pdf. (Accessed: 2 August 2020)

Espey, J. and Revi, A. (2018) 'Translating Global Vision into Local Reality : Building the right knowledge and policy infrastructure to support local sustainable development Urban 20 White Paper About Urban 20 About the White Papers', Urban 20 White Paper, p. 28. Available at: http://www.urban20.org/item/ejes-y-documentosclave/U20_WP_Knowledge_and_policy_for_local_development.pdf. (Accessed: 2 March 2020)

Ferdandez-Maldonado, A. M. (2016) 'Planeamiento urbano y produccion de vivienda en el Peru', in Procesos Urbanos en Accion. ¿Desarrollo de ciudades para todos?. 1st edn. Quito: Ediciones AbyaYala, pp. 71-105. (Accessed: 2 March 2020) 
Fernández-Maldonado, A. M. (2019) 'Unboxing the Black Box of Peruvian Planning', Planning Practice and Research. Routledge, 34(4), pp. 368-386. doi: 10.1080/02697459.2019.1618596.

García Q., R. et al. (2015) 'Desarrollo o crecimiento urbano en Lima: el caso de los distritos del Sur', Perú Hoy, pp. 223-247. Available at: http://www.desco.org.pe/recursos/site/files/CONTENIDO/28/10_GarcíaR_PH_dic_15.pdf. (Accessed: 2 March 2020)

Global Taskforce; UN-Habitat; UNDP (2016) 'Roadmap for localizing the SDGs: Implementation and Monitoring at subnational level', p. 44. Available at: https://sustainabledevelopment.un.org/content/documents/commitments/818_11195_commit ment_ROADMAP LOCALIZING SDGS.pdf. (Accessed: 2 March 2020)

Gómez-Álvarez, D. et al. (2017) Steering the Metropolis: Metropolitan Governance for Sustainable Urban Development, Washington: IDB. Steering the Metropolis: Metropolitan Governance for Sustainable Urban Development. IDB. doi: 10.18235/0000875.

Independent Group of Scientists (2019) 'Global Sustainable Development Report 2019: The Future is Now - Science for Achieving Sustainable Development.', New York: United Nations, pp. 27-107. doi: 10.1016/j.aodf.2009.10.015.

Instituto Metropolitano de Planificacion (IMP) and Municipalidad Metropolitana de Lima (MML) (2020) 'Vision de Desarrollo Urbano para la Metropoli. PLANMET 2040', Lima: Instituto Metropolitano de Planificacion - IMP, pp. 3-14. Available at: https://www.imp.gob.pe/images/PLANMET2040/240720_VISION_DOSSIER HORIZONTAL (1).pdf. (Accessed: 5 August 2020)

Integracion, I. de A. y C. (2020) 'Las oportunidades de la ciudad', I Foro "Ciudades con Futuro" Lima: Grupo RPP, pp. 1-20. Available at: https://f.rpp-noticias.io/2020/02/26/informe-las-oportunidades-dela-ciudad_905997.pdf. (Accessed: 29 February 2020)

Inter American Development Bank (2020) 'La Crisis de la Desigualdad. America Latina y el Caribe en la encrucijada', $\quad$ p. $409 . \quad$ Available at: https://publications.iadb.org/publications/spanish/document/La-crisis-de-la-desigualdadAmerica-Latina-y-el-Caribe-en-la-encrucijada.pdf. (Accessed: 23 September 2020)

lovene, M. et al. (2018) 'Towards Informal Planning: Mapping the Evolution of Spontaneous Settlements in Time.', 24th ISUF International Conference. Book of Papers. Valencia: Universitat Politècnica de València, pp. 545-557. doi: 10.4995/isuf2017.2017.5441.

Jordán, R., Riffo, L. and Prado, A. (2017) 'Desarrollo sostenible, urbanización y desigualdad en América Latina y el Caribe', (LC/PUB.2017/19), Santiago: Comision Economica para America Latina y el Caribe (CEPAL), pp. 215-218. Available at: https://www.cepal.org/es/publicaciones/42141desarrollo-sostenible-urbanizacion-desigualdad-america-latina-caribe-dinamicas. (Accessed: 31 January 2020)

Kanuri, C. et al. (2016) 'Getting Started with the SDGs in Cities. A guide for stakeholders.', Sustainable Development Solutions Network - SDSN, pp. 11-100. doi: 10.1007/978-1-4302-4000-6_2.

Leon, J. (2018) 'El proyecto que intenta evitar derrumbes en cerros habitados', Lima: El Comercio Newspaper, p. 1. Available at: https://elcomercio.pe/lima/sucesos/riesgo-pais-proyecto-evitarderrumbes-cerros-habitados-noticia-491396-noticia/. (Accessed: 16 August 2020) 
Lozano, V. (2018) 'Forestacion para proteger y ordenar', El Peruano Newspaper - Economika, 18 March. Available at: https://elperuano.pe/suplementosflipping/economika/256/web/pagina02.html. (Accessed: 16 August 2020)

Marcés, R., Miyashiro, J. and Wiese, C. (2016) 'Desigualdad urbana en Lima Metropolitana', in Desigualdad y desarrollo. Serie: Peru Hoy N³0. 1st edn. Lima: Desco, pp. 333-368. Available at: http://www.desco.org.pe/recursos/site/files/CONTENIDO/1117/15_WieseUrb_PH_dic16.pdf. (Accessed: 2 March 2020)

Metzger, P. et al. (2015) 'Atlas problemático de una metrópoli vulnerable. Desigualdades urbanas en Lima y Callao', Lima: Instituto Francés de Estudios Andinos - IFEA, pp. 1-40. Available at: http://www.ifea.org.pe/libreria/travaux/331/pdf/atlas-problematico-es.pdf. (Accessed: 21 January 2020)

Ministerio de Vivienda (2016a) 'Decreto Supremo No222-2016-Vivienda. Reglamento de Acondicionamiento Territorial y Desarrollo Urbano Sostenible (RATDUS)'. Available at: https://ww3.vivienda.gob.pe/DGPRVU/docs/DUDU/01 RATDUS - DS 022-2016-Viviend.pdf. (Accessed: 21 January 2020)

Ministerio de Vivienda (2016b) 'Informe Nacional - Habitat III', Ministerio de Vivienda, pp. 6-124. Available at: http://habitat3.org/wp-content/uploads/National-Report-LAC-Peru-Spanish.pdf. (Accessed: 21 January 2020)

Ministerio de Vivienda (2018) 'Proyecto de Ley de Desarrollo Urbano Sostenible'. Available at: http://www.leyes.congreso.gob.pe/Documentos/2016_2021/Proyectos_de_Ley_y_de_Resolucio nes_Legislativas/PL0402220190308.pdf. (Accessed: 21 January 2020)

Municipalidad de Independencia; Centro de Estudios y Prevencion de Desastres - PREDES (2018a) 'Plan de Prevencion y Reduccion de Riesgos de Desastres 2018-2021. Distrito de Independencia', Lima: Centro de Estudios y Prevencion de Desastres (PREDES), pp. 15-35. Available at: https://www.predes.org.pe/wp-content/uploads/2018/07/PPRRD-Independencia.pdf. (Accessed: 21 January 2020)

Municipalidad de Independencia; Centro de Estudios y Prevencion de Desastres - PREDES (2018b) 'Propuesta de Actualizacion y Reajuste de Zonificacion de los Usos del Suelo. Distrito de Independencia', Lima: Centro de Estudios y Prevencion de Desastres (PREDES), pp. 4-25. Available at: $\quad$ http://www.predes.org.pe/wp-content/uploads/2018/11/Propuesta-ZonificaciónReglamentos_MDI.pdf. (Accessed: 9 August 2020)

Sachs, J. et al. (2020) 'The Sustainable Development Goals and COVID-19. Sustainable Development Report 2020', Cambridge: Cambridge University Press., pp. 374-375. Available at: https://s3.amazonaws.com/sustainabledevelopment.report/2020/2020_sustainable_developme nt_report.pdf. (Accessed: 30 June 2020)

UN-Habitat (2015a) Iniciativa de las ciudades prósperas y con futuro. Lima., Nairobi: UN-Habitat. Available at: http://cpi.unhabitat.org/sites/default/files/resources/Lima_Book.pdf. (Accessed: 30 June 2020)

UN-Habitat (2015b) 'International Guidelines on Urban and Territorial Planning', Nairobi: UN-Habitat, pp. 1-32. doi: 10.1136/jme.27.2.117.

UN-Habitat (2015c) 'PLAM 2035. Sistematizacion del Plan del Area Metropolitana de Lima-Callao 2035', Nairobi: UN-Habitat, pp. 1-33. Available at: https://uni.unhabitat.org/wpcontent/uploads/2015/06/PLAM2035_150614.pdf. (Accessed: 21 January 2020) 
Torres, $\mathbf{S}$.

One Metropolis, two scenarios.

Sustainable Urban Development Contradictions

in the Metropolitan Area of Lima

UN-Habitat (2020) 'Global State of Metropolis 2020 - Population Data Booklet', UN-Habitat, HS/013/20E, p. 22. Available at: https://unhabitat.org/es/global-state-of-metropolis-2020--population-databooklet. (Accessed: 30 June 2020)

United Nations (2015) 'Transforming our world: The 2030 Agenda for sustainable development', United Nations Resolution A/RES/70/1, pp. 5-17. doi: 10.1201/b20466-7.

United Nations (Habitat III) (2017) New Urban Agenda. United Nations. Available at: www.habitat3.org. (Accessed: 13 March 2020)

Williams, K. (2010) 'Sustainable cities: Research and practice challenges', International Journal of Urban Sustainable Development, 1(1-2), pp. 128-132. doi: 10.1080/19463131003654863.

Winchester, L. (2006) 'Desafíos para el desarrollo sostenible de las ciudades en América Latina y El Caribe', Eure, 32(96), pp. 7-25. doi: 10.4067/s0250-71612006000200002.

World Bank (2015) Peru. Hacia un sistema integrado de ciudades. 1st edn, Lima: World Bank. 1st edn. Available at: http://documents1.worldbank.org/curated/en/981211468196152402/pdf/101383REVISED-PUBLIC-SPANISH-ciudadesweb.pdf. (Accessed: 13 March 2020) 